\title{
Metabolic activity associated with lacustrine seston
}

\author{
Arkadi S. Parparov ${ }^{1, *}$, Tom Berman ${ }^{1}$, Hans-Peter Grossart ${ }^{2}$, Meinhard Simon ${ }^{2}$ \\ ${ }^{\prime}$ Israel Oceanographic and Limnological Research, The Yigal Allon Kinneret Limnological Laboratory, PO Box 345, \\ Tiberias 14102, Israel \\ ${ }^{2}$ Limnologisches Institut, Universität Konstanz, PO Box 5560, D-78434 Konstanz, Germany
}

\begin{abstract}
The metabolic activity associated with seston in Lake Kinneret, Israel, was estimated as specific (per unit dry weight, DW, or particulate organic carbon, POC) respiration during experimental studies in 1995. Some determinations of oxygen demand by seston and lake snow aggregates were also carried out in Lake Constance, Germany. About 86 and $84 \%$ of the variation in total community respiration in the epilimnetic water of Lake Kinneret could be explained by the variability of seston dry weight and the POC content, respectively. The mean specific respiration of seston was $0.10 \pm 0.006 \mathrm{mg}$ $\mathrm{O}_{2} \mathrm{mgDW}^{-1} \mathrm{~d}^{-1}$ (or $0.07 \pm 0.005 \mathrm{mg} \mathrm{C} \mathrm{mgPOC}^{-1} \mathrm{~d}^{-1}$ ). These values characterize the seston as a metabolically active compartment of the lake ecosystem with a mean turnover time of about $14 \mathrm{~d}$. Experiments with aggregated seston of different origins indicated a tendency toward decreasing specific metabolic activities with increasing aggregate size. The mean specific biomass production of sestonassociated bacteria was $0.014 \pm 0.001 \mathrm{mg} \mathrm{C} \mathrm{mgPOC}^{-1} \mathrm{~d}^{-1}$. The theoretical limit of the growth efficiency of seston-associated bacteria was also estimated using the parameters of specific respiration and specific bacterial production.
\end{abstract}

KEY WORDS: Lake Kinneret - Lake Constance - Seston - Metabolic activity - Respiration Bacterial production

\section{INTRODUCTION}

The suspended matter in aquatic ecosystems (seston) incorporates many levels of organization, and can be considered conceptually as a higher hierarchical level than its separate components (Ostapenia 1989). Seston may be subdivided into living (phytoplankton, bacteria, protozoa, zooplankton) and dead (detritus) fractions. The living communities, a minor part of seston mass, carry out their metabolic activities within a complex of interactions with detritus, forming an indivisible metabolically active community (Wetzel et al. 1972, Ostapenia 1989). The cycling of suspended matter in aquatic ecosystems can be described in terms of a seston budget (Sheng \& Lick 1979, Parparov 1987, Van Maldegem et al. 1993) which depends on sources (riverine input, resuspension, photosynthetic and physico-chemical formation) and sinks (biological decomposition, physico-chemical dissolution and sedimentationj. Disturbances of this cycle significantly affect the

\footnotetext{
•E-mail: parpar@ocean.org.il
}

stability of the entire ecosystem (Serruya 1975, Martynova 1984). The ecological significance of the seston in any given environment will be determined by its role in the recycling processes of organic matter, nutrients and sedimentation. Additionally, organic particles may serve as a principal source of food for proto- and metazooplankton. The dense colonization of particles by microorganisms mediates and often intensifies the transitions between dissolved organic matter and particulate organic matter (Wetzel et al. 1972, Khailov 1974, Paerl 1974, Smith et al. 1992, Müller-Niklas et al. 1994).

Despite the obvious ecological importance of the seston, studies of its overall cycling and properties in freshwater ecosystems are rare. Most investigations have focused on transformations of specific components of seston, for example as a part of nutrient cycling. Thus, extensive investigations of spatiotemporal dynamics of particulate organic carbon (POC) were carried out as part of studies of the aquatic carbon cycles (Wetzel 1984, Forsberg 1985, Cole et al. 1989, Bloesch \& Uehlinger 1990). These authors 
applied methods of population ecology to the dynamics of POC concentration and estimated the metabolic activity of this fraction as specific rates of production and elimination, and as turnover time of suspended POC. A similar approach was developed by Tilzer (1984) to estimate loss rates of the phytoplankton biomass in Lake Constance.

Systematic investigations of seston carried out in lakes in Belarus were summarized by Ostapenia (1989), who suggested that the metabolic activity of suspended matter could be estimated in terms of oxygen demand by seston, normalized to seston dry weight or POC (specific seston oxygen demand, SSOD). Ostapenia (1989) evaluated the variability of this parameter for different water bodies, and, on the basis of estimates of turnover rates of the seston, he concluded that seston as a whole is a metabolically active compartment of lacustrine ecosystems. In the systems studied, Ostapenia (1989) showed that aged seston did not accumulate in the water column due to its short turnover time (ca $10 \mathrm{~d}$ ). A similar concept of 'turnover time' was used by Grossart \& Simon (1993) to evaluate the intensity of the microbial transformation of macroaggregates (lake snow) in Lake Constance.

Biological breakdown and sedimentation are the most important sinks for seston (Skopintsev 1979, Eppley et al. 1983, Ostapenia 1989, Bloesch \& Uehlinger 1990). Decomposition may occur by enzymatic solubilization or by aerobic oxidation (respiration) of particulate organic matter (POM) by various biotic components. This breakdown will result to a great extent in the mineralization (as $\mathrm{CO}_{2}$ ) of organic carbon. Determination of specific respiration rates (expressed as SSOD) is a direct way to estimate the metabolic activity associated with suspended matter. As yet, there are only a few reports of such determinations, despite a significant increase of sensitivity and precision of the Winkler oxygen method, which came from the application of coulometric titrators (Graneli \& Graneli 1991). The losses of seston due to respiration can also be estimated by measurements of the electron transport system (ETS) activity (Packard 1971), which provide an indirect measurement of potential respiration.

The determination of the impact of attached bacteria on the metabolic activity of seston is another important consideration. Simultaneous measurements of SSOD and parameters of microbial activity (such as respiration and production) have not been previously reported, though the importance of such measurements has been emphasized (Pomeroy et al. 1994, Jahnke \& Craven 1995).

The objective of our study was to estimate the metabolic activities of suspended matter and its associated microflora in terms of respiration and to evaluate their impact on the total community metabolism.

\section{MATERIALS AND METHODS}

Field collections and experimental observations were carried out in 1995, mainly in Lake Kinneret, Israel; some measurements of seston oxygen demand were also made in Lake Constance, Germany. Parallel determinations of seston oxygen demand and bacterial production were carried out in Lake Kinneret in autumn 1995.

Lake Kinneret is a warm monomictic lake located at $-210 \mathrm{~m}$ mean sea level in the northern part of the AfroSyrian Rift Valley. The limnology of the lake is well documented (Serruya 1978). The lake is $22 \mathrm{~km}$ long and $12 \mathrm{~km}$ at maximum width maximum and mean depths are $42 \mathrm{~m}$ and $24 \mathrm{~m}$, respectively, and the surface area is $170 \mathrm{~km}^{2}$. From May to December the lake is stratified, with surface temperatures ranging from 12 to $30^{\circ} \mathrm{C}$ and a seasonal thermocline at $15 \mathrm{~m}$. The hypolimnion is anoxic from June to November. The main inflow (about $80 \%$ of the total) comes via the Jordan River. The lake is meso-eutrophic with a mean annual primary production of $600 \mathrm{~g} \mathrm{C} \mathrm{m}^{-2}$ (Berman et al. 1992, 1995). The water level of the lake depends on climatic inputs and withdrawal for water supply (Serruya 1978). Secchi depths vary from 0.7 to $5.5 \mathrm{~m}$ and turbidity from 0.7 to $22 \mathrm{NTU}$ (nephelometer turbidity units) (Parparov 1993). A prominent biological feature of the lake is the late winter-early spring bloom of the dinoflagellate Peridinium gatunense. During this study the cyanobacterium Microcystis aeruginosa often was a dominant component of the phytoplankton. The annual average seston concentration in the euphotic zone of Lake Kinneret is $3.2 \mathrm{mg} \mathrm{l}^{-1}$ (Parparov unpubl.); phytoplankton and zooplankton comprise about 16 and $8 \%$ of this quantity, respectively [our estimates based on data of Berman et al. (1992) and Gophen (1995)].

Lake Constance is a large (surface area $571 \mathrm{~km}^{2}$, mean depth $100 \mathrm{~m}$ ) pre-alpine, warm monomictic lake. Between 1945 and 1980, the lake was intensely eutrophied, and after the reduction of external phosphorus loading, the lake again became mesotrophic (Gaedke \& Schweizer 1993). The anmual succession of phytoplankton can be subdivided into 4 phases: (1) a bloom of cryptophytes and diatoms in spring, (2) a clear-water phase, (3) the bloom of large diatoms in summer, and (4) a dominance of the green algae and colony-forming cyanobacteria (Microcystis spp.) in autumn.

Following Ostapenia (1989), we suggest that respiration is an integrative characteristic of the metabolic activity of suspended matter. Total community respiration of the water column, $R_{\text {rom, }}$ can be represented as the sum of the respiration of seston-associated microorganisms (including algae and attached heterotrophic microorganisms, $R_{\text {part }}$ ) and the respiration of free-living 
bacteria, $R_{\mathrm{fb}}$. We are aware that some free-living bacteria are also a component of the seston, which is defined here as all particulates collected on a Whatman GF/F filter with a mean pore size of $\sim 0.7 \mu \mathrm{m}$. However, in order to differentiate between the respiration of the larger, non-bacterial POC by seston-associated microorganisms and the respiration processes of the dissolved phase by free-living bacteria, we define $R_{\text {com }}$ as follows:

$$
R_{\text {com }}=R_{\text {part }}+R_{\mathrm{fb}}
$$

$R_{\text {part }}$ is assumed to be proportional to the concentration of particles (expressed either as dry weight, DW, or as POC), and therefore

$$
R_{\text {com }}=a \times \mathrm{DW}(\text { or } \mathrm{POC})+b
$$

where the slope (a) of the equation is the SSOD due to respiration by suspended matter and the constant ( $b$ ) is an estimate of $R_{\mathrm{fb}}$. Following this approach, the parameters of Eq. (2) were obtained by calculating the regression of measured values of $R_{\text {com }}$ versus DW (or POC) in a series of experiments in which particles were added at increasing concentrations to lake water samples. Also, these parameters were estimated by analyzing the regressions obtained from a series of experiments based on sampling at different times and locations.

Water samples and lake snow aggregates in Lake Kinneret were collected from different depths at a central station (A, $42 \mathrm{~m}$ ) and a littoral station (, $23 \mathrm{~m}$ ). Lake seston was concentrated by different procedures: (1) by reverse filtration of $20 \mathrm{l}$ through nylon screens of different mesh sizes, (2) by direct collection. with nylon nets, and (3) by collection of settling particles (tripton) in sediment traps deployed at 15 to $25 \mathrm{~m}$ depth for 1 to $3 \mathrm{~d}$. Aggregates of Microcystis aeruginosa colonies were collected by SCUBA divers. For experiments with Lake Constance samples, aggregates were produced by incubating lake water in rolling tanks at in situ temperature according to Shanks \& Edmondson (1989).

Total community respiration was determined by the standard dark bottle method (APHA 1985). Oxygen bottles were incubated at in situ temperature for $24 \mathrm{~h}$. Rates of oxygen consumption in Lake Constance remained linear for $48 \mathrm{~h}$ (Simon 1985). Dissolved oxygen concentrations were measured by the azide modification of the Winkler method (APHA 1985) in 3 replicates. High precision $( \pm 2.0 \mu \mathrm{ll})$ titration with thiosulfate was carried out with a $719 \mathrm{~S}$ Titrino Metrohm coulometric titrator (Graneli \& Graneli 1991). The conversion factor 0.3 was used to convert respiration from $\mathrm{mg}$ $\mathrm{O}_{2}$ to $\mathrm{mg} \mathrm{C}$.

The potential activity of the electron transport system (ETS) was determined using the tetrazolium reduction technique of Packard (1971) as modified by Rai (1984). Seston samples were collected in triplicate on Whatman GF/F filters, homogenized in phosphate buffer, sonicated, and centrifuged at $5000 \mathrm{rpm}$ $(1500 \times \mathrm{g})$ for $5 \mathrm{~min}$. A $1 \mathrm{ml}$ aliquot was taken from each cell homogenate and placed in a test tube with $3 \mathrm{ml}$ of substrate buffer and $1 \mathrm{ml}$ of 2 -(4-iodophenyl)3-(4-nitrophenyl)-5-phenyltetrazolium chloride (INT) solution. The samples were then incubated for $20 \mathrm{~min}$ in the dark at in situ temperature. The reaction was stopped by adding $1 \mathrm{ml}$ of a $1: 1(\mathrm{v} / \mathrm{v})$ solution of $1 \mathrm{M}$ $\mathrm{H}_{3} \mathrm{PO}_{4}$ and concentrated Formalin, and, after another centrifugation at $3000 \mathrm{rpm}(900 \times g)$ for $5 \mathrm{~min}$, absorbance at $490 \mathrm{~nm}$ was determined in a Kontron spectrophotometer. The absorbance of the samples was converted to rates of oxygen reduction using the equation of Packard \& Williams (1981).

Bacterial biomass production (BBP) was determined by the incorporation of $\left[{ }^{14} \mathrm{C}\right]$-leucine (leu; Simon \& Azam 1989) into the ice-cold trichloroacetic acid (TCA) fraction. Incubation of untreated water samples and a Formalin-killed control was done in triplicate at $30 \mathrm{nM}$ leu and in situ temperature in the dark. The microbial activity was stopped after $1 \mathrm{~h}$ with Formalin. The final concentration of added $\left[{ }^{14} \mathrm{C}\right]$-leu in untreated water samples included a 1:3 dilution with non-radiolabeled leucine. Based on determinations of saturating kinetics, much higher final concentrations of leu were used for water samples enriched with seston, i.e. 250 to 300 $\mathrm{nM}$. To measure BBP of particle associated bacteria only, the samples were collected on Whatman GF/C filters with a mean pore size of $1.2 \mu \mathrm{m}$. Leucine incorporation rates $\left(l e u_{\text {inc }}\right)$ were converted to BBP according to Simon \& Azam (1989):

$$
\mathrm{BBP}=\operatorname{leu}_{\mathrm{inc}} \times 1797 \times F l \times I D
$$

where $F l$ is the fraction of $\operatorname{leu}_{\mathrm{nc}}$ in the hot TCAinsoluble material as a percent of the ice-cold TCA precipitate $(0.85)$ and $I D$ is the intracellular isotope dilution of leucine (assumed to be 2).

The following parameters of suspended matter were determined: (1) Dry weight (DW) was measured gravimetrically after samples were filtered through preweighed Whatman GF/F filters and dried to constant weight at $70^{\circ} \mathrm{C}$. (2) POC was determined as $50 \%$ of the loss on ignition of $\mathrm{POM}$ at $550^{\circ} \mathrm{C}$ on the filters previously used for measuring DW (Golterman 1970). The POC content of seston in Lake Kinneret estimated by dichromate combustion varied from 0.45 to 0.55 of POM. Therefore, we consider POC to be $50 \%$ of POM as a reasonable mean for Lake Kinneret samples. DW and POC were measured in duplicates; the difference between duplicates never exceeded $10 \%$.

Three subsets of data were used to calculate regressions of metabolic parameters versus particle concen- 
Table 1. Parameters of the regression equations. $r^{2}$ : correlation coefficient; p: probability; n: number of determinations. DW: dry weight; POC: particulate organic carbon; $R_{\mathrm{ETS}}$ : respiratjon measured as the potential activity of the electron transport system; $R_{\text {com: }}$ total community respiration of the water column; $R_{\mathrm{O}_{2}}$ respiration measured directly as $\mathrm{O}_{2}$ uptake; $\mathrm{BBP}$ : bacterial biomass production

\begin{tabular}{|c|c|c|c|c|c|c|}
\hline Eq. & $X$ & $Y$ & Equation & $r^{2}$ & $\mathrm{p}$ & $\mathrm{n}$ \\
\hline $4^{a}$ & $\begin{array}{l}\text { DW } \\
\left(\mathrm{mg} \mathrm{l}^{-1}\right)\end{array}$ & $\begin{array}{l}R_{\mathrm{rom}} \\
\left(\mathrm{mg} \mathrm{O}_{2} \mathrm{l}^{-1} \mathrm{~d}^{-1}\right)\end{array}$ & $Y=(0.082 \pm 0.016) X+(0.18 \pm 0.26)$ & 0.56 & 0.01 & 23 \\
\hline $5^{a}$ & $\begin{array}{l}\mathrm{POC} \\
\left(\mathrm{mg} \mathrm{l}^{-1}\right)\end{array}$ & $\begin{array}{l}R_{\mathrm{com}} \\
\left(\mathrm{mg} \mathrm{O} \mathrm{O}_{2} \mathrm{l}^{-1} \mathrm{~d}^{-1}\right)\end{array}$ & $Y=(0.072 \pm 0.011) X+(0.06 \pm 0.06)$ & 0.68 & 0.01 & 23 \\
\hline $6^{b}$ & $\begin{array}{l}\mathrm{DW} \\
\left(\mathrm{mg} \mathrm{l} \mathrm{l}^{-1}\right)\end{array}$ & $\begin{array}{l}R_{\text {com }} \\
\left(\mathrm{mg} \mathrm{O}_{2} \mathrm{l}^{-1} \mathrm{~d}^{-1}\right)\end{array}$ & $Y=(0.10 \pm 0.006) X+(0.17 \pm 0.24)$ & 0.86 & 0.001 & 38 \\
\hline $7^{b}$ & $\begin{array}{l}\mathrm{POC} \\
\left(\mathrm{mg} \mathrm{l}^{-1}\right)\end{array}$ & $\begin{array}{l}R_{\mathrm{com}} \\
\left(\mathrm{mg} \mathrm{Cl} \mathrm{l}^{-1} \mathrm{~d}^{-1}\right)\end{array}$ & $Y=(0.07 \pm 0.005) X+(0.095 \pm 0.085)$ & 0.84 & 0.001 & 38 \\
\hline $8^{d}$ & $\begin{array}{l}R_{\mathrm{ETS}} \\
\left(\mathrm{mg} \mathrm{O}_{2} \mathrm{l}^{-1} \mathrm{~d}^{-1}\right)\end{array}$ & $\begin{array}{l}R_{\mathrm{O}_{2}} \\
\left(\mathrm{mg} \mathrm{O} \mathrm{O}_{2} \mathrm{l}^{-1} \mathrm{~d}^{-1}\right)\end{array}$ & $Y=(0.40 \pm 0.09) X+(0.32 \pm 0.27)$ & 0.56 & 0.01 & 17 \\
\hline $9^{b}$ & $\begin{array}{l}R_{\mathrm{ETS}} \\
\left(\mathrm{mg} \mathrm{O}_{2} \mathrm{l}^{-1} \mathrm{~d}^{-1}\right)\end{array}$ & $\begin{array}{l}R_{\mathrm{O}_{2}} \\
\left(\mathrm{mg} \mathrm{O} \mathrm{O}_{2} \mathrm{l}^{-1} \mathrm{~d}^{-1}\right)\end{array}$ & $Y=(0.47 \pm 0.037) X+(0.076 \pm 0.29)$ & 0.78 & 0.001 & 31 \\
\hline $10^{\mathrm{a}}$ & $\begin{array}{l}\text { DW } \\
\left(\mathrm{mg} \mathrm{l}^{-1}\right)\end{array}$ & $\begin{array}{l}R_{\mathrm{ETS}} \\
\left(\mathrm{mg} \mathrm{O}_{2} \mathrm{l}^{-1} \mathrm{~d}^{-1}\right)\end{array}$ & $Y=0.18 X^{087}$ & 0.39 & 0.01 & 16 \\
\hline $11^{\mathrm{a}}$ & $\begin{array}{l}\mathrm{POC} \\
\left(\mathrm{mg} \mathrm{l}^{-1}\right)\end{array}$ & $\begin{array}{l}R_{\mathrm{ETS}} \\
\left(\mathrm{mg} \mathrm{Cl}^{-1} \mathrm{~d}^{-1}\right)\end{array}$ & $Y=0.13 X$ & 0.54 & 0.01 & 16 \\
\hline $12^{c}$ & $\begin{array}{l}R_{\mathrm{ETS}} \\
\left(\mathrm{mg} \mathrm{O}_{2} \mathrm{l}^{-1} \mathrm{~d}^{-1}\right)\end{array}$ & $\begin{array}{l}\left.R_{\mathrm{O}_{2}} \mathrm{O}_{2} \mathrm{l}^{-1} \mathrm{~d}^{-1}\right) \\
(\mathrm{mg}\end{array}$ & $Y=(0.57 \pm 0.06) X+(0.076 \pm 0.29)$ & 0.90 & 0.001 & 12 \\
\hline $13^{d}$ & $\begin{array}{l}R_{\mathrm{ETS}} \\
\left(\mathrm{mg} \mathrm{O} \mathrm{O}^{-1} \mathrm{~d}^{-1}\right)\end{array}$ & $\begin{array}{l}R_{\mathrm{O}_{2}} \\
\left(\mathrm{mg} \mathrm{O}_{2} \mathrm{I}^{-1} \mathrm{~d}^{-1}\right)\end{array}$ & $Y=(0.523 \pm 0.038) X+(0.089 \pm 0.294)$ & 0.83 & 0.001 & 42 \\
\hline $14^{b}$ & $\begin{array}{l}\text { DW } \\
\left(\mathrm{mg} \mathrm{l}^{-1}\right)\end{array}$ & $\begin{array}{l}\mathrm{BBP} \\
\left(\mathrm{mg} \mathrm{O} \mathrm{O}_{2} \mathrm{l}^{-1} \mathrm{~d}^{-1}\right)\end{array}$ & $Y=(0.014 \pm 0.001) X+\{0.009 \pm 0.06\}$ & 0.79 & 0.001 & 29 \\
\hline $15^{\mathrm{b}}$ & $\begin{array}{l}\mathrm{POC} \\
\left(m g l^{-1}\right)\end{array}$ & $\begin{array}{l}\mathrm{BBP} \\
\left(\mathrm{mg} \mathrm{C} \mathrm{l}^{-1} \mathrm{~d}^{-1}\right)\end{array}$ & $Y=(0.014 \pm 0.001) X+(-0.002 \pm 0.013)$ & 0.88 & 0.001 & 29 \\
\hline \multicolumn{7}{|c|}{${ }^{\mathrm{a}}$ Untreated water samples } \\
\hline
\end{tabular}

trations: (1) untreated water samples, taken at different times and locations, (2) lake water samples with increasing particle concentrations ( 4 or 5 concentrations added in each experiment, and (3) the entire data set. The regression equations are summarized in Table 1.

\section{RESULTS}

\section{Respiration versus seston concentration}

\section{Untreated samples}

Determinations of $R_{\text {com }}$ and seston parameters in Lake Kinneret were carried out from March until November 1995. The phytoplankton was dominated either by Peridinium gatunense or Microcystis aeruginosa and in one instance in autumn also by Aulacoseira granulata. Community respiration of the untreated water samples varied from $0.26 \mathrm{mg} \mathrm{O}_{2} \mathrm{l}^{-1} \mathrm{~d}^{-1}$ in September to $1.41 \mathrm{mg} \mathrm{O} \mathrm{I}^{-1} \mathrm{~d}^{-1}$ in March. The dry weight of seston ranged from 2.14 to $13.4 \mathrm{mg}^{-1}$, and POC comprised about 35 to $40 \%$ of the seston dry weight. $R_{\text {com }}$ of untreated lake water samples showed signifi- cant correlations with either seston dry weight or with POC concentration (Eqs. 4 \& 5 in Table 1).

From these equations, specific respiration rates (given by the slope of the regressions) were 0.082 $( \pm 0.016) \mathrm{mg} \mathrm{O}_{2} \mathrm{mgDW}^{-1} \mathrm{~d}^{-1}$ and $0.072( \pm 0.011) \mathrm{mg} \mathrm{C}$ mgPOC ${ }^{-1} \mathrm{~d}^{-1}$, respectively. The latter estimate gives a turnover time of $13.9 \mathrm{~d}$ for POC due to respiration.

The estimated $R_{\mathrm{fb}}$ (given by the regression constant) was not significantly different from zero; however, note the mean values: $0.18 \mathrm{mg} \mathrm{O}_{2} \mathrm{l}^{-1} \mathrm{~d}^{-1}$ (or $0.06 \mathrm{mg}$ $\mathrm{Cl}^{-1} \mathrm{~d}^{-1}$ ).

\section{Experiments with added seston}

Specific respiration obtained from the experimental series in which increasing amounts of seston were added to lake water varied from 0.05 to $0.37 \mathrm{mg} \mathrm{O} \mathrm{O}_{2}$ $\mathrm{mgDW}^{-1} \mathrm{~d}^{-1}$, with a mean value of $0.11 \mathrm{mg} \mathrm{O}_{2} \mathrm{mgDW}^{-1}$ $\mathrm{d}^{-1}\left(0.08 \mathrm{mg} \mathrm{C} \mathrm{mgPOC}{ }^{-1} \mathrm{~d}^{-1}\right.$; Table 1$)$. The mean turnover time of seston due to respiration as calculated by this approach was $11.5 \mathrm{~d}$. The highest specific respiration (fastest turnover time) was recorded during the breakdown of the Peridinium gatunense bloom at the 


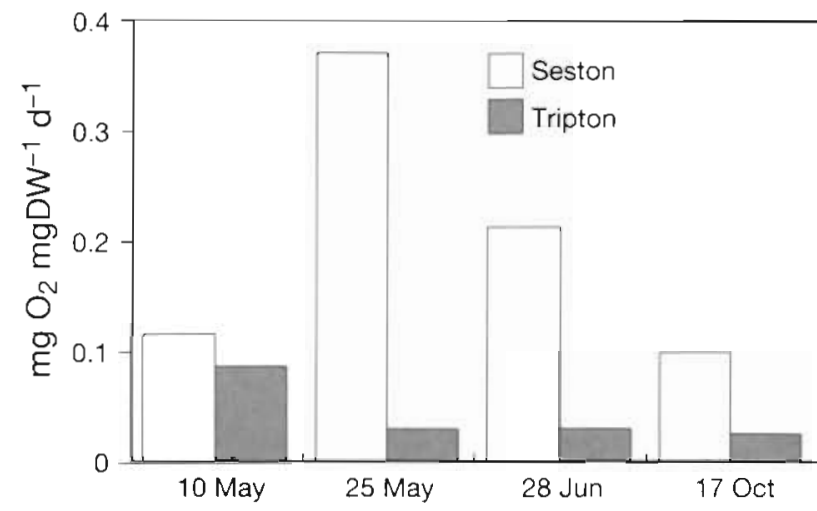

Fig. 1. Specific respiration of particles collected in sediment traps (tripton) and of suspended particles (seston) in Lake Kinneret, Israel

end of May. On average, respiration associated with suspended matter comprised $64 \%$ of $R_{\text {com }}$, with a range from 26 to $85 \%$. For the same period, $R_{\mathrm{fb}}$ ranged from 15 to $74 \%$ of $R_{\text {com. }}$. Note that the mean estimate of $R_{\mathrm{fb}}$ $\left(0.24 \mathrm{mg} \mathrm{O}_{2} \mathrm{l}^{-1} \mathrm{~d}^{-1}\right)$ was close to that calculated by Eq. (4).

These experiments revealed significant differences in the metabolic activity of suspended matter from the euphotic zone or from the near bottom layer. The specific respiration of the seston was much higher in the upper water layers than in the hypolimnion, 0.082 and $0.016 \mathrm{mg} \mathrm{O}_{2} \mathrm{mgDW}^{-1} \mathrm{~d}^{-1}$, respectively. The respiration of seston was the dominant fraction of the $R_{\text {com }}$ in the upper water layers but only a minor component of $R_{\text {com }}$ in the deeper waters (81 and $5 \%$, respectively).

The comparison of the metabolic activity of suspended particles (seston) and particulate material collected in sediment traps (tripton, Fig. 1) showed that the specific respiration of tripton particles (mean $0.03 \mathrm{mg} \mathrm{O}_{2} \mathrm{mgDW}^{-1} \mathrm{~d}^{-1}$ ) was generally much lower than that of seston $\left(0.10\right.$ to $0.37 \mathrm{mg} \mathrm{O}_{2} \mathrm{mgDW}^{-1} \mathrm{~d}^{-1}$, see also Eqs. 4 \& 5 in Table 1 ).

Aggregates ( $>1 \mathrm{~mm}$; agr) collected by SCUBA divers in the epilimnetic water of Lake Kinneret during September and October 1995 mainly consisted of Microcystis aeruginosa macrocolonies. Difficulties in sampling and processing these aggregates allowed us to carry out only a few experiments. The photosynthesis associated with these aggregates was about $10 \%$ of total plankton photosynthesis. Respiration associated with aggregates was $<1 \%$ of total community respiration (the mean concentration of aggregates in near surface waters during this period was $20 \mathrm{agr}^{-1}$ ). Because of the low rates of specific respiration associated with these aggregates (ca $0.5 \mu g \mathrm{O}_{2} \mathrm{agr}^{-1} \mathrm{~d}^{-1}$ ), we were unable to measure oxygen uptake directly. Instead, the respiration rates of these aggregates were determined

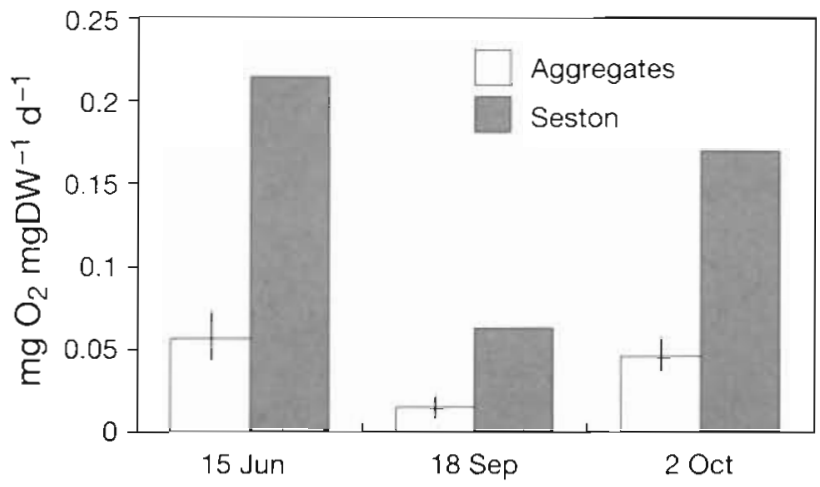

Fig. 2. Specific respiration of aggregates and seston [calculations based on electron transport system (ETS) measurements]. Upper and lower boundaries assuming $R_{\text {com }}$ (total community respiration of the water column) $=0.5$ ETS and $R_{\text {com }}=$ ETS, respectively. See text for details

using the ETS assay. We estimated upper and lower limits for the specific respiration, taking into account the variability of conversion factors from ETS to respiration. Therefore, we took ETS $=R_{\text {com }}$ and ETS $=2 \times$ $R_{\text {com }}$ as lower and upper limits, respectively (Packard \& Williams 1981). In all experiments, the specific oxygen demand by aggregates was lower than that of seston (Fig. 2). Note that smaller aggregates ( $2 \mu \mathrm{g} \mathrm{POC} \mathrm{agr}{ }^{-1}$ ), collected on October 2 , had relatively greater activity than larger ones (14 $\mu \mathrm{g}$ POC $\mathrm{agr}^{-1}$ ), sampled on September 18 (Table 2).

Pooling all data from the untreated water samples and from the particle addition experiments yielded a close correlation between $R_{\text {com }}$ and the structural parameters of suspended matter (POC and DW, Fig. 3; Eqs. 6 \& 7 in Table 1) despite the different origin of the particulates. The specific respiration rates of suspended matter given by these equations were $0.1 \pm$

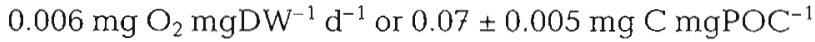
$\mathrm{d}^{-1}$, corresponding to a mean seston turnover time of 14.3 d. Between 84 and $86 \%$ of the variability of the community respiration was explained by the variability of POC and DW of the seston.

Table 2. Dry weight (DW), particulate organic carbon (POC), specific rates of photosynthesis and respiration, and $\mathrm{POC}$ turnover rates of aggregates (agr) collected on 18 September and 2 October 1995 in Lake Kinneret

\begin{tabular}{|lcc|}
\hline Parameter & 18 Sep & 2 Oct \\
\hline DW, mg agr & & \\
POC, $\mathrm{mg} \mathrm{agr}^{-1}$ & 0.041 & 0.009 \\
Specific photosynthesis, $\mu \mathrm{g} \mathrm{Cagr}^{-1} \mathrm{~h}^{-1}$ & 0.014 & 0.002 \\
Specific respiration, $\mu \mathrm{g} \mathrm{O} \mathrm{agr}^{-1} \mathrm{~h}^{-1}$ & 0.1 & 0.1 \\
Specific respiration, $\mathrm{mg} \mathrm{O}_{2} \mathrm{mgDW}^{-1} \mathrm{~d}^{-1}$ & 0.019 & 0.5 \\
POC turnover rate, $\mathrm{d}$ & 50 & 14.5 \\
\hline
\end{tabular}




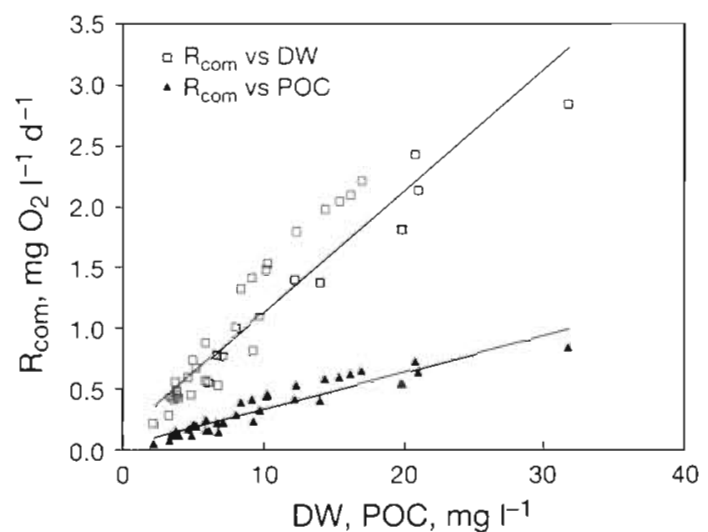

Fig. 3. Relationships of community respiration ( $\left.R_{\text {com }}\right)$ to dry weight (DW) and to POC from the pooled data sets of untreated samples and experiments with added seston from Lake Kinneret. The correlation equations (Eqs. 6 \& 7) are given in Table 1

Respiration of different size fractions of the seston (collected by 60 and $140 \mu \mathrm{m}$ mesh net) in Lake Constance was relatively higher than for Lake Kinneret seston, especially for the larger size fractions (Table 3 ). However, the values from Lake Constance may have been affected by the high abundance of large $(>100 \mu \mathrm{m})$ zooplankton (mostly Daphnia spp.). This suggestion was confirmed indirectly by the levels of SSOD in the $<60 \mu \mathrm{m}$ fraction (free of Daphnia) in Lake Constance, which were similar to those in Lake Kinneret.

The respiration of particulate material collected in sediment traps in Lake Constance at $25 \mathrm{~m}$ depth was estimated for 2 fractions separated by differential settling (Table 3). Both fractions had relatively low specific respiration rates, presumably because of the high mineral content of these particles (POM was only 9 to $12 \%$ of dry weight).

The aggregates produced in rolling tanks from Lake Constance samples were relatively large and dense

Table 3. Dry weight (DW) of aggregates and rates of respiration for seston and aggregates from Lake Constance samples of July 1995

\begin{tabular}{lcc}
\hline & Dry weight & Specific respiration \\
\hline Aggregates & $0.5 \mathrm{mg}^{2} \mathrm{agr}^{-1}$ & $0.005 \mathrm{mg} \mathrm{O}_{2} \mathrm{agr}^{-1} \mathrm{~d}^{-1}$ \\
& $0.009 \mathrm{mg} \mathrm{O}_{2} \mathrm{mg} \mathrm{DW}^{-1} \mathrm{~d}^{-1}$ \\
Net seston (specific respiration) \\
$>140 \mu \mathrm{m}$ & $0.26-0.70 \mathrm{mg} \mathrm{O}_{2} \mathrm{mgDW}^{-1} \mathrm{~d}^{-1}$ \\
$<60 \mu \mathrm{m}$ & $0.06 \mathrm{mg} \mathrm{O}_{2} \mathrm{mgDW}^{-1} \mathrm{~d}^{-1}$ \\
Sediment trap particles (specific respiration) \\
Slow settling & $0.007 \mathrm{mg} \mathrm{O}_{2} \mathrm{mgDW}^{-1} \mathrm{~d}^{-1}$ \\
Fast settling & $0.004 \mathrm{mg} \mathrm{O}_{2} \mathrm{mgDW}^{-1} \mathrm{~d}^{-1}$
\end{tabular}

$(1.0 \mathrm{~cm}$ in diameter and $0.5 \mathrm{mg}$, respectively) compared to those observed in Lake Kinneret (few $\mathrm{mm}$ and 9 to $41 \mu \mathrm{g}$, Table 3 ). The dry weight specific oxygen demand by the aggregates from Lake Constance was low, 5.0 to $9.0 \mu \mathrm{g} \mathrm{O}_{2} \mathrm{mgDW}^{-1} \mathrm{~d}^{-1}$ (Table 3).

\section{Relationship between respiration and ETS}

The main reason for the use of the ETS assay in these experiments was to exploit a simple, rapid method to estimate respiration in water samples. Because the ETS assay gives an estimate of the potential community respiration, a constant relationship between respiration measured directly as $\mathrm{O}_{2}$ uptake, $R_{\mathrm{O}_{2}}$, and ETS activity, $R_{\text {ETS }}$ might not necessarily be expected. Nevertheless, for untreated water samples our data showed a moderately close linear relationship between these 2 parameters (Eq. 8, Table 1). Combining the data of untreated samples with those of the added seston significantly improved the correlation (Eq. 9, Table 1). Similar to $R_{\mathrm{O}_{2}}, R_{\mathrm{ETS}}$ appeared to be related to the dry weight and POC content of seston, but with weaker correlations (Eqs. $10 \& 11$, Table 1).

The regression of ETS versus $R_{\text {com }}$ (Eq. 12, Table 1 ) was similar to that for Lake Kinneret. Combining the data for the both lakes (Fig. 4 and Eq. 13, Table 1) gives a reasonable interrelationship $\mathrm{ETS}=0.5 R_{\text {com }}$.

\section{Biomass production of seston-associated bacteria}

Biomass production of seston-associated bacteria, $\mathrm{BBP}$, in untreated samples from Lake Kinneret varied from 0.4 to $1.3 \mu \mathrm{g} \mathrm{C}^{-1} \mathrm{~h}^{-1}$. Usually, BBP increased with the total mass of seston, but in several experiments

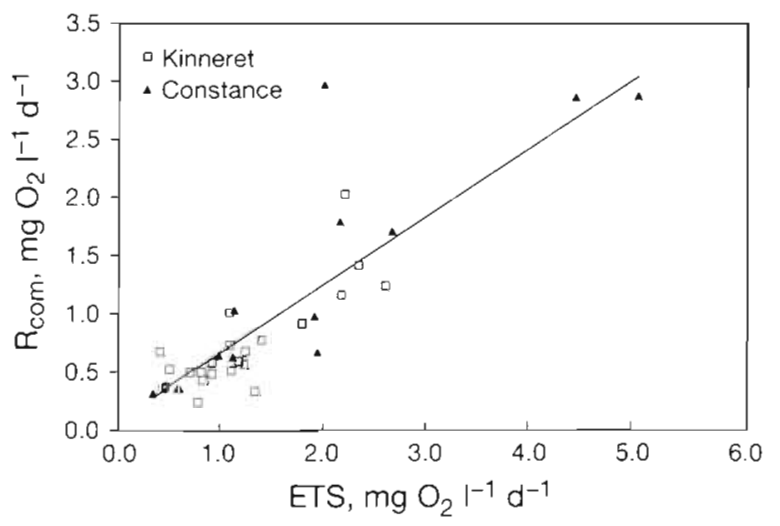

Fig. 4. Relationship of community respiration $\left(R_{\text {com }}\right)$ to respiration measured as the potential activity of the electron transport system (ETS) for untreated water samples from Lake Kinneret and Lake Constance. The correlation equation (Eq. 13) is given in Table 1 
with added seston BBP declined at the highest seston concentrations. By pooling all data we obtained a close correlation between BBP and seston parameters (Fig. 5, Eqs. $14 \& 15$, Table 1). The slope of the regression with POC implies that POC is decomposed on the basis of BBP, with a turnover rate of about $1.4 \%$ per day. Note that the constant in Eqs. (14) \& (15) is not significantly different from zero. This implicitly confirms our suggestion (see 'Materials and methods') that total $\mathrm{BBP}$, including that of free-living and of sestonassociated bacteria, is largely dominated by the production, and presumably also by the respiration $\left(R_{\text {part }}\right)$, of the seston-associated bacteria.

Specific BBP for macroaggregates composed mainly of Microcystis aeruginosa colonies was significantly lower than that of seston: $0.12 \pm 0.03$ and $14 \pm 1 \mu \mathrm{g} \mathrm{C}$ $\mathrm{mgPOC}^{-1} \mathrm{~d}^{-1}$, respectively.

BBP was significantly $(\mathrm{p}<0.005)$ correlated with $R_{\text {com }}$ and varied from 12.6 to $30.9 \%$ of $R_{\text {com }}$, with a mean of $20 \%$. The highest $\mathrm{r}^{2}$ values were obtained for a power function and a reciprocal correlation $(0.55$ and 0.66 , respectively). In both cases, these regression equations indicate that the increase of $R_{\text {com }}$ was associated with a relatively greater increase in BBP.

\section{DISCUSSION}

\section{Specific respiration of seston and aggregates}

Calculations based on different data sets gave similar estimates of the metabolic activity of Lake Kinneret seston expressed as specific respiration (Eqs, 4 to 7 , Table 1). The mean specific respiration of $0.10 \pm$ $0.006 \mathrm{mg} \mathrm{O}_{2} \mathrm{mgDW}^{-1} \mathrm{~d}^{-1}$ is very close to the annual average of $0.11 \mathrm{mg} \mathrm{O}_{2} \mathrm{mgDW}^{-1} \mathrm{~d}^{-1}$ reported for a previous data set from this lake by Parparov (1994). The similarity of the results obtained for different data sets in this study (untreated water samples and samples with added seston) suggests that the experimental increase in the range of seston concentrations did not significantly affect the main features of respiration. The observed values of specific respiration showed relatively low variability and may be a general characteristic of suspended matter from Lake Kinneret

These rates of seston respiration in Lake Kinneret are at the high end of the range of the limited data reported in the literature (Table 4). They are higher than decomposition rates for natural plankton communities, which

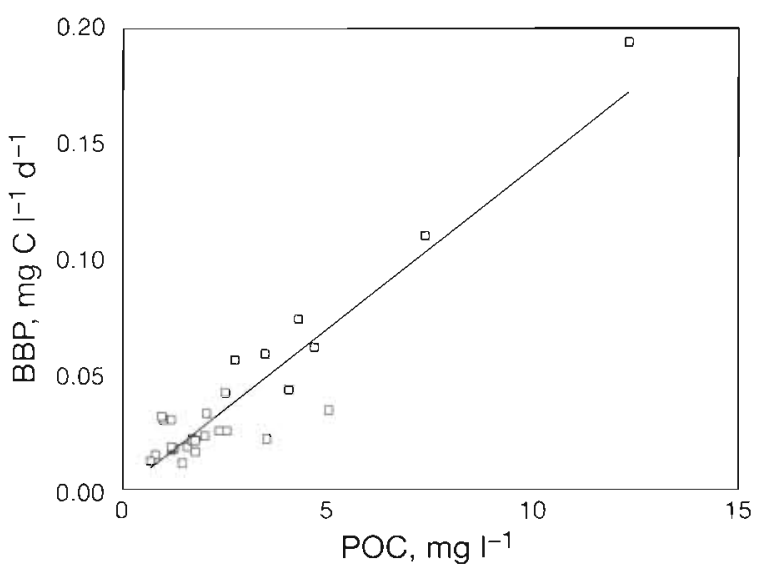

Fig. 5. Relationship of bacterial biomass production (BBP) to POC. The correlation equations (Eqs. $14 \& 15$ ) are given in Table 1

were measured from changes in seston DW over time, with a mean of $0.058 \mathrm{~d}^{-1}$ (see review of Enriquez et al. 1993). This might be explained by a higher metabolic activity of attached bacteria in Lake Kinneret, possibly due to higher water temperatures than those found in the other aquatic systems listed in Table 4. The similarity between parameters of the regression equations $R_{\text {com }}$ versus DW and $R_{\text {com }}$ versus POC is due to the close correlation between DW and POC (A. Parparov \& Y Yacobi unpubl.). A similar rate of decomposition of lacustrine POM $\left(0.1 \mathrm{~d}^{-1}\right)$ was reported by Wetzel (1984). Skopintsev et al. (1979) made a detailed study of the decomposition rates of lake seston during a 1 yr period in which changes of seston DW and POC over time were monitored. Our calculations based on data of Skopintsev et al. (1979) indicate that the dynamics of DW in these experiments could be described best by an inverse logarithmic correlation (Fig. 6; curve III, $\mathrm{r}^{2}=$ $0.91, p<0.001$ ). The initial $6 \mathrm{~d}$ period of a relatively fast

Table 4. Dry Weight specific respiration of seston of different waterbodies ( $\mathrm{mg} \mathrm{O}_{2} \mathrm{mgDW}^{-1} \mathrm{~d}^{-1}$ )

\begin{tabular}{|c|c|c|}
\hline Waterbody & cific respiration & Source \\
\hline Naroch, Belarus & 0.061 & Ostapenia (1989) \\
\hline Miastro, Belarus & 0.047 & Ostapenia (1989) \\
\hline Batorin, Belarus & 0.037 & Ostapenia (1989) \\
\hline Nero, Volga region, Russia & $0.06-15$ & Larionov (1979) \\
\hline Sevan, Armenia & 0.07 & Glooshchenko (1988) \\
\hline Ribinskoie Reservoir, Russia & $0.052-0.078$ & $\begin{array}{l}\text { Bicbulatov \& Bicbulatova } \\
\text { (1979) }\end{array}$ \\
\hline Lucerne, Switzerland & 0.07 & Bloesch \& Uehlinger (1992) \\
\hline Kinneret, Israel & 0.10 & This study \\
\hline Constance, Germany ${ }^{b}$ & 0.06 & This study \\
\hline Weddell \& Scotia Seas, Antarctica & 0.051 & Estrada et al. (1992) \\
\hline
\end{tabular}




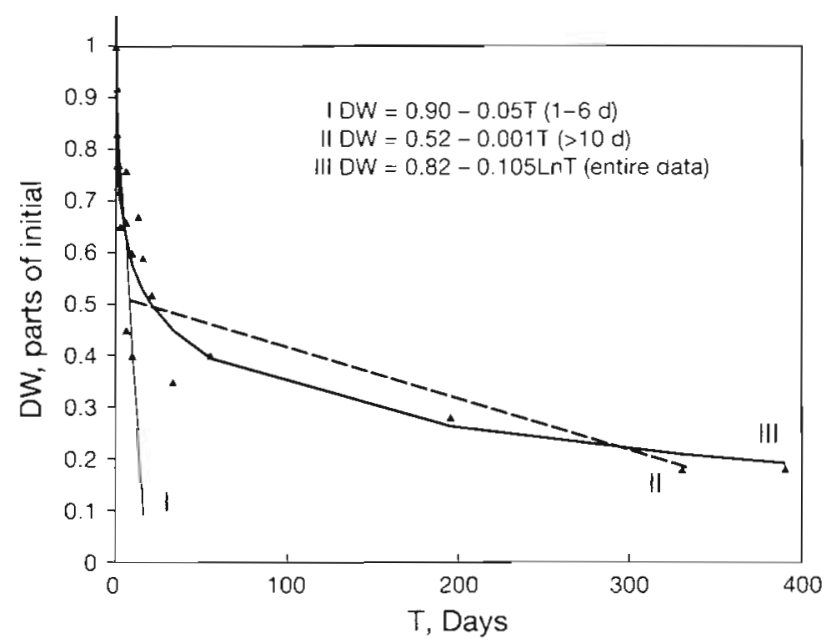

Fig. 6. Decrease of dry weight of lacustrine particulate organic matter (POM) over time at oxic conditions (data derived from Tables 4, 6 \& 10 of Skopintsev et al. 1979)

loss of DW reflects the decomposition of the labile fraction of seston, followed after $10 \mathrm{~d}$ by a much slower rate of decomposition of more refractory components. These 2 periods can be approximated by 2 linear regressions (Fig. 6 ; lines I and II) with slopes of $0.05 \pm$ 0.015 and $0.0001 \pm 0.00002 \mathrm{~d}^{-1}$, respectively. These values are close to the specific respiration rates obtained in our experiments for less degraded particulates (seston) and more degraded suspended matter (tripton), respectively.

The mean daily loss rate of euphotic POC by respiration was $0.07 \mathrm{~d}^{-1}$. Estimates of loss rates of POC by sedimentation in Lake Kinneret, another major sink for euphotic POC, vary from 0.006 to $0.025 \mathrm{~d}^{-1}$ (N. Koren pers. comm.). Losses by sedimentation were calculated as follows: (1) sedimentation of POC was assumed to be $13 \%$ of primary production (Serruya 1977), (2) primary productivity averaged $1.63 \mathrm{mg} \mathrm{C} \mathrm{m}{ }^{-2} \mathrm{~d}^{-1}$ (Berman et al. 1995), (3) the annual mean POC was $1.35 \mathrm{mg} \mathrm{l}^{-1}$ (Parparov unpubl.), and (4) the mean depth of the lake is $24 \mathrm{~m}$. Hence, losses of euphotic POC by respiration are 3 - to 12 -fold higher than by sedimentation. Based on the estimates above, the total loss rates of seston (respiration plus sedimentation) range from 0.076 to $0.095 \mathrm{~d}^{-1}$. These should be considered as low estimates of overall losses of seston in the euphotic zone of Lake Kinneret due to the assumptions involved.

These turnover rates of suspended matter, which we determined for the euphotic zone, are lower than, but of the same order of magnitude as, the mean turnover rates of phytoplankton in Lake Kinneret, $0.14 \mathrm{~d}^{-1}$, as calculated on the basis of data of Berman et al. (1992, 1995). Our data emphasize that respiration is an important sink of suspended POC from the euphotic zone in Lake Kinneret. Similar findings were reported for other lakes (Tilzer 1984, Ostapenia 1989, Bloesch \& Uehlinger 1990). Our study also supports Ostapenia's (1989) ideas that seston should be regarded as a metabolically active compartment of freshwater ecosystems and that the level of this activity is mainly determined by the structural properties of the seston (DW and POC).

The range of seston turnover rates shown in Table 4 is relatively narrow $\left(0.037\right.$ to $\left.0.10 \mathrm{mg} \mathrm{O}_{2} \mathrm{mgDW}^{-1} \mathrm{~d}^{-1}\right)$. Although these data were derived from a limited number of aquatic ecosystems, they do represent different trophic levels and different geographic zones and, therefore, suggest a general range for the magnitude of the seston-associated metabolic activity (specific respiration) in freshwater ecosystems.

The aggregation of small seston particles may be considered as a shift of the particle size distribution towards larger size fractions. The impact of size structure on the metabolic activity of seston and plankton has been extensively discussed, and the inverse dependence of respiration of plankters and seston particles with their mass is well known (Suschchenia 1972, Ostapenia 1989, Gaedke 1993). Specific metabolic activity (e.g. respiration and photosynthesis) is usually higher for smaller organisms and particles.

In addition to measuring specific respiration of bulk POM, we also determined specific respiration of different size fractions of POM and macroscopic aggregates of various origin. These results indicate a tendency toward lower specific respiration rates for natural aggregates (Lake Kinneret) and aggregates formed in rolling tanks (Lake Constance) as compared to those of natural seston, which often is composed of smaller size fractions than the aggregates $\left(0.001 \mathrm{~d}^{-t}\right.$ and $0.07 \mathrm{~d}^{-1}$, respectively).

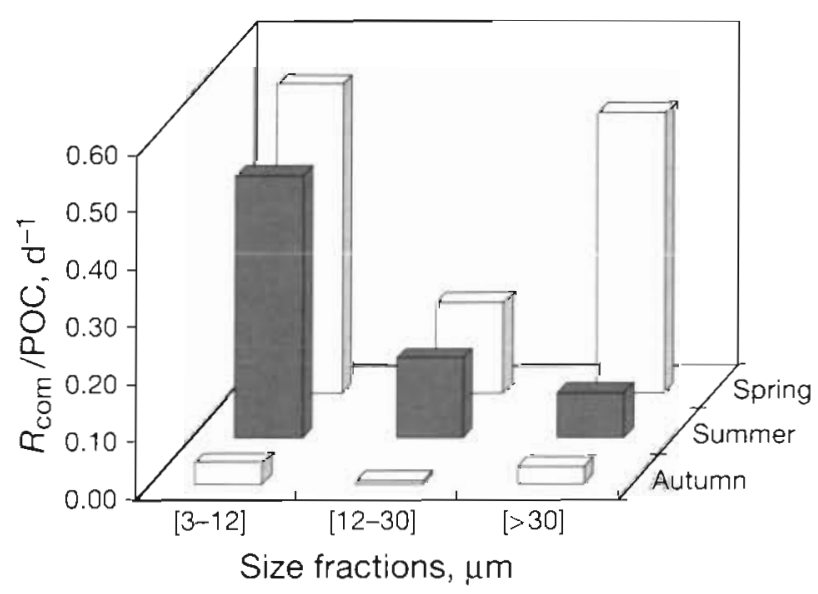

Fig. 7. Ratios of community respiration $\left(R_{\mathrm{rom}}\right)$ over POC of seston of Lake Lucerne for different size fractions $(\geq 3 \mu \mathrm{m})$. Data were calculated from Table 3 and Figs. 2 \& 3 of Bloesch \& Uehlinger (1990) 
Our calculations, based on data of Bloesch \& Uehlinger (1990), also indicated a tendency toward lower specific respiration of larger $(\geq 3 \mu \mathrm{m})$ particles in Lake Lucerne (Fig. 7). It has also been shown that the DW-specific colonization and growth of bacteria on marine aggregates is inversely correlated to the size and DW of aggregates (Alldredge \& Gotschalk 1990). Ostapenia (1989) showed that different size fractions of lake seston have approximately equal total free surface area and thus concluded that the metabolic activity of different seston size fractions is also approximately similar. This consideration leaves open the question of how the total metabolic activity, e.g. respiration, changes when several small and densely colonized particles aggregate to a larger particle which has fractal geometry (Li \& Logan 1995). Our study indicates that weight-specific metabolic rates of seston size fractions cannot be simply translated from natural POM to aggregates such as marine snow and lake snow, which obviously exhibit specific properties due to their peculiar structure.

\section{Impact of particle-associated bacteria in cycling of POC}

Our determinations of POC turnover rates due to particle-associated bacteria (i.e. POC-specific production rates $\left.=0.014 \mathrm{~d}^{-1}, \mathrm{Eq} .15\right)$ are the first estimates of this parameter for Lake Kinneret. We found only a few comparable references in the literature. Kirchman (1983) found turnover rates of POC by production of attached bacteria in a freshwater pond ranging from $9 \times 10^{-5}$ to $6 \times 10^{-3} \mathrm{~d}^{-1}$. Simon (1987) estimated turnover times of $\mathrm{POC}$ by bacterial production in Lake Constance as $40 \mathrm{~d}$, corresponding to turnover rates of $0.025 \mathrm{~d}^{-1}$. These rates are in the same range as $\mathrm{POC}$ turnover times determined for bulk POC (Eppley et al. 1983) and marine snow aggregates in the Southern California Bight of the Pacific (Simon et al. 1990). From data of Alldredge et al. (1995) and Smith et al. (1995), who studied the aggregation and microbial breakdown of a diatom bloom in a marine mesocosm, we calculated a POC turnover rate of $0.001 \mathrm{~d}^{-1}$. This value is identical to the turnover rates for aggregates of Microcystis aeruginosa colonies observed in Lake Kinneret. All these very slow POC turnover times demonstrate that bacterial biomass net-production cannot be the only sink for POC because total POC turnover is much faster (see above). Hence, other processes such as solubilization and respiration by bacteria or other microbes must contribute as well. It has been shown that particle-associated bacteria rapidly solubilize POM and organic aggregates, thus releasing specific labile organic compounds such as amino acids and carbohydrates (Smith et al. 1992, Müller-Niklas et al. 1994, Berman et al. 1997).

The growth efficiency $[\mathrm{GE}=\mathrm{BBP} /(\mathrm{BBP}+$ Respiration)] of free-living bacteria utilizing ambient concentrations of dissolved organic matter usually ranges between about 10 and $40 \%$ (equivalent to 60 to $90 \%$ respiration), depending on the type and degradability of the substrate and the bacterial growth rate (Tranvik 1988, Kristiansen et al. 1992, Middelboe \& Søndergaard 1993). For particle-associated bacteria, growth efficiencies have not yet been determined, with the exception of work done by Smith et al. (1995), who estimated a growth efficiency of particle-associated bacteria of 9 to $17 \%$ during the breakdown of a diatom bloom.

We estimated the growth efficiency of particleassociated bacteria from our data by using the results for POC, $R_{\text {com }}, \mathrm{BBP}$ and the specific rates of respiration and bacterial production. Respiration of seston $\left(R_{\text {part }}\right)$ can be considered as the sum of respiration of attached bacteria $\left(R_{\mathrm{b}}\right)$ plus the respiration of other components $\left(R_{\mathrm{r}}\right)$ of the seston associated community (algae, protoand metazooplankton) as follows:

$$
R_{\text {part }}=R_{\mathrm{b}}+R_{\mathrm{r}}
$$

Combining Eq. (16) with Eqs. (1) \& (2), and taking into account that the constant $b=R_{\mathrm{fb}}$ (in Eq. 2), we obtain the following equation:

Since

$$
R_{\mathrm{b}}+R_{\mathrm{r}}=a \times \mathrm{POC}
$$

$$
\mathrm{BBP}=d \times \mathrm{POC}
$$

we obtain the following estimate of the GE:

$$
\mathrm{GE}=d \times \mathrm{POC} /\left(a \times \mathrm{POC}+d \times \mathrm{POC}-R_{\mathrm{r}}\right)
$$

where $a$ and $d$ are the slopes of the correlation equations of $R_{\text {com }}$ and BBP, respectively, versus POC, and $R_{\mathrm{r}}$ is the non-bacterial component of seston respiration. If $R_{\mathrm{r}}=0$ (i.e. assuming that seston respiration is entirely bacterial), then $R_{\text {part }}=R_{\mathrm{b}}$, and we receive a theoretical minimum for the GE $\left(G E_{\min }\right)$ based on the linear relationship of $R_{\text {com }}$ (or $\mathrm{BBP}$ ) versus POC as follows:

$$
\mathrm{GE}_{\min }=d /(a+d)
$$

Substitution of ' $a$ ' and ' $d$ ' from Eqs. (7 \& 14) respectively gives for Lake Kinneret $\mathrm{GE}_{\min }=0.014 /(0.014+$ $0.070)=0.17$.

These GEs of particle-associated bacteria are at the low end of GEs of free-living bacteria but fairly close to the GE estimated by Smith et al. (1995) for particleassociated bacteria and thus appear to confirm our indirect approach for calculating the GE.

In conclusion, we note that in this study metabolic activity associated with seston was estimated on the basis of respiration only. However, in addition to respi- 
ration, bacteria also solubilize part of the POC, thus further enhancing the turnover rate. We did not investigate the processes of transfers between solid and liquid phases, which are strongly mediated by the metabolism of biota (Wetzel et al. 1972). So far there is only some preliminary information available on the relative significance of respiration versus solubilization (Berman et al. 1998), but it appears that that the latter process may have considerable influence in seston decomposition.

Acknowledgements. We thank A. P. Ostapenia and 3 anonymous reviewers for their valuable comments and criticism which significantly improved the manuscript. We also thank $N$. Koren for discussion and assistance in the aggregate sampling. This research is part of the joint German-Israeli research project supported by the Joint German-Israeli Research Program (BMBFA-DISUM grant D0032-GR 01420).

\section{LITERATURE CITED}

Alldredge AL, Gotschalk C (1990) The relative contribution of marine snow of different origins to biological processes in coastal waters. Cont Shelf Res 10:41-58

Alldredge AL, Gotschalk C, Passow U, Riebesell U (1995) Mass aggregation of diatom blooms: insights from a mesocosm study. Deep Sea Res 42:9-27

APHA (American Public Health Association) (1985) Standard methods for the examination of water and wastewater. 16th edn. APHA, Washington, DC, p 1268

Berman T, Parparov A, Simon M (1998) Carbon fluxes in limnetic seston: relative significance of respiration, solubilization and nonphotosynthetic formation. Arch Hydrobiol (in press)

Berman T, Simon M, Parparov A (1997) An approach to evaluate carbon fluxes during formation and break-down of aquatic particulates. ASLO Aquatic Sciences Meeting, Santa Fe, USA, p 97 (abstract)

Berman T, Stone L, Yacobi YZ, Kaplan B, Schlichter $M$, Nishri A, Pollinger U (1995) Primary production and phytoplankton in Lake Kinneret: a long-term record. (1972-1993). Limnol Oceanogr 40:1064-1076

Berman T, Yacobi YZ, Pollinger U (1992) Lake Kinneret phytoplankton: stability and variability during twenty years (1970-1989). Aquat Sci 54:104-127

Bicbulatov ES, Bicbulatova YM (1979) Rate of decomposition of organic matter of dead phytoplankton. In: Romanenko VI, Skopintsev BA (eds) Microbiological and chemical processes of decomposition of organic matter in waterbodies. Nauka, Leningrad, p 213-224 (in Russian)

Bloesch J, Uehlinger U (1990) Epilimnetic carbon flux and turnover of different particle size classes in oligomesotrophic Lake Lucerne. Switzerland. Arch Hydrobiol 118:403-419

Cole JJ, Caraco NF, Strayer DL, Ochs C, Nolan. S (1989) A. detailed carbon budget as an ecosystem-level calibration of bacterial respiration in an oligotrophic lake during midsummer. Limnol Oceanogr 34:286-296

Enriquez S, Duarte CM, Sand-Jensen K (1.993) Patterns in decomposition rates among photosynthetic organisms: the importance of detritus C:N:P content. Oecologia 90: $457-471$

Eppley RW, Renger EH, Betzer PR (1983) The residence time of particulate organic carbon in the surface layer of the ocean. Deep Sea Res 30:311-323

Estrada M, Martinez R, Mother S (1992) Respiratory electron transport activity in plankton of the Weddell and Scotia Seas during late spring-early summer: relationships with other biological parameters. Plant Biol 12:35-42

Forsberg BR (1985) The fate of planktonic primary production. Limnol Oceanogr 30:807-819

Gaedke U (1993) Ecosystem analysis based on biomass size distributions: a case study of a plankton community in a large lake. Limnol Oceanogr 38:112-127

Gaedke U, Schweizer A (1993) The first decade of oligotrophication in Lake Constance. 1. The response of the phytoplankton biomass and cell size. Oecologia 93:268-275

Glooshchenko LO (1998) Particulate organic matter and its role in the formation of water quality in Lake Sevan. Proc Intern Conf Reserv Limnol Water Quality. Ceské-Budëjovice 15-20

Golterman HL (1970) Methods for chemical analysis of fresh waters. IBP Handbook No. 8. Blackwell, Oxford

Gophen M (1995) Long-term (1970-1990) whole lake biomanipulation experience. Case study: Lake Kinneret (Israel) In: De Bernardi R, Giussani $G$ (eds) Guidelines in lake management, Vol 7 , Biomanipulation in lakes and reservoir management. International Lake Environment Committee, United Nations Environment Programme, p 171-184

Graneli A, Graneli E (1991) Automatic potentiometric determination of dissolved oxygen. Mar Biol 108:341-348

Grossart HP, Simon M (1993) Limnetic macroscopic organic aggregates (lake snow): occurrence, characteristics, and microbial dynamics in Lake Constance. Limnol Oceanogr 38:532-546

Jahnke RA, Craven DB (1995) Quantifying the role of heterotrophic bacteria in the carbon cycle: a need for respiration rate measurements. Limnol Oceanogr 40:436-441

Khailov KM (1974) The biochemical trophodynamics in coastal sea ecosystems. Naukova Dumka, Kiyev (in Russian)

Kirchman D (1983) The production of bacteria attached to particles suspended in a freshwater pond. Limnol Oceanogr 28:858-872

Kristiansen K, Nielsen H, Riemann B, Fuhrman JA (1992) Growth efficiencies of freshwater bacterioplankton. Microb Ecol 24:145-160

Larionov YV (1979) Kinetics of biochemical oxygen demand by suspended matter and impact of dissolved organic matter on its formation. In: Romanenko VI, Skopintsev BA. (eds) Microbiological and chemical processes of decomposition of organic matter in waterbodies. Nauka, Leningrad, p 225-235 (in Russian)

Li X, Logan BE (1995) Size distributions and fractal properties of particles during a simulated phytoplankton bloom in a mesocosm. Deep Sea Res 42:125-138

Martynova MV (1984) Nitrogen and phosphorus in bottom sediments of lakes and reservoirs. Nauka, Moscow (in Russian!

Middelboe M, Søndergaard M (1993) Bacterioplankton growth yield: seasonal variations and coupling to substrate availability and $\beta$-glucosidase activity. A.ppl Environ Microbiol 59:3916-3921

Müller-Niklas G, Schuster S, Kaltenböck E, Herndl GJ (1994) Organic content and bacterial metabolism in amorphous aggregates of the northern Adriatic Sea. Limnol Oceanogr 39:58-68

Ostapenia AP (1989) Seston and detritus as structural and functional components of water ecosystems. Ref Diss, Minsk (in Russian) 
Packard TT (1971) The measurement of respiratory electron transport activity in marine phytoplankton. J Mar Res 37: $711-742$

Packard TT, Williams PJleB (1981) Rates of respiratory oxygen consumption and electron transport in surface seawater from the northwest Atlantic Ocean. Oceanol Acta 4:351-358

Paerl HW (1974) Bacterial uptake of dissolved organic matter in relation to detrital aggregation in marine and freshwater systems. Limnol Oceanogr 19:966-972

Parparov A.S (1987) Method of evaluation of interrelation between formation and dissolution of suspended matter in the process of sedimentation in water bodies. Vodnye Resursy (Water Resources) 1:179-181 (in Russian)

Parparov AS (1993) Effects of seston on parameters of the underwater light field of Lake Kinneret. Optical properties and quantum yield of aquatic photosynthetic systems. Proc BSF-IUI Workshop, November 21-26, 1993, Eilat, Israel (Book of Abstracts), p 28-29

Parparov AS (1994) Oxygen depletion in lake Kinneret: longterm trends and new events. Limnologica 24:137-145

Pomeroy LR, Sheldon RE, Sheldon WM Jr (1994) Changes in bacterial numbers and leucine assimilation during estimations of microbial respiratory rates in seawater by the precision Winkler method. Appl Environ Microbiol 60: $328-332$

Rai $H$ (1984) Activity of the respiration electron transport system (ETS) in different size particles as a measure of carbon losses from primary producers. Int Rev Ges Hydrobiol 73:617-625

Serruya C (1975) Nitrogen and phosphorus balances and load-biomass relationship in Lake Kinneret (Israel). Verh Int Verein Limnol 19:1357-1369

Serruya C (1977) Rates of sedimentation and resuspension in Lake Kinneret. In: Golterman HL (ed) Interactions between sediments and fresh water. Proc Int SIL-UNESCO Symp. Junk, The Hague, p 48-56

Serruya C (1978) Lake Kinneret. Monographiae Biologique, No. 32, W Junk, The Hague

Shanks AL, Edmondson EW (1989) Laboratory-made artificial marine snow: a biological model of the real thing. Mar Biol 101:463-470

Sheng YP, Lick W (1979) The transport and resuspension of sediments in a shallow lake. J Geophys Res 84:1809-1826

Simon M (1985) The significance of free-living and particleassociated bacteria for the cycling of matter in Lake Con-

Editorial responsibility: John Dolan,

Villefranche-sur-Mer, France stance. PhD thesis, University of Konstanz (in German)

Simon M (1987) Biomass and production of small and large free-living and attached bacteria in Lake Constance. Limnol Oceanogr 32:591-607

Simon M, Alldredge AL, Azam F (1990) Bacterial carbon dynamics on marine snow. Mar Ecol Prog Ser 65:206-211

Simon M, Azam F (1989) Protein content and protein synthesis rates of planktonic marine bacteria. Mar Ecol Prog Ser 51:201-213

Skopintsev BA (1979) Suspended and dissolved organic matter in natural waters according to field and experimental data. In: Romanenko VI, Skopintsev BA (eds) Microbiological and chemical processes of decomposition of organic matter in waterbodies. Nauka, Leningrad, p 236-256 (in Russian)

Skopintsev BA, Bicbulatov ES, Bicbulatova YM, Melnicov NI (1979) Changes of the chemical composition of water and suspended matter under aerobic decomposition of phytoplanktonic organic matter. In: Romanenko VI, Skopintsev BA (eds) Microbiological and chemical processes of decomposition of organic matter in waterbodies. Nauka, Leningrad, p 159-186 (in Russian)

Smith DC, Simon M, Alldredge AL, Azam F (1992) Intense hydrolytic enzyme activity on marine aggregates and implications for rapid particle dissolution. Nature 359: $139-142$

Smith DC, Steward GF, Long RA, Azam F (1995) Bacterial mediation of carbon flux during a diatom bloom in a mesocosm. Deep Sea Res 42:75-97

Suschchenia LM (1972) Intensity of respiration of crustacea. Naukova Dumka, Kiev

Tilzer MM (1984) Estimation of phytoplankton loss rates from daily photosynthetic rates and observed biomass changes in Lake Constance. J Plankton Res 6:309-324

Tranvik L (1988) Availability of dissolved organic carbon for planktonic bacteria in oligotrophic lakes of different humic content. Microb Ecol 16:311-322

Van Maldegem DC, Mulder HPJ, Langerak L (1993) A cohesive sediment balance for the Schelde Estuary. Neth J Aquat Ecol 27:247-256

Wetzel RG (1984) Detrital dissolved and particulate organic carbon functions in aquatic ecosystems. Bull Mar Sci 35: 503-509

Wetzel RG, Rich PH, Miller MC, Allen HL (1972) Metabolism of dissolved and particulate detrital carbon in a temperate hard-water lake. Mem Ist Ital Idrobiol 28(Suppl):185-243

Submitted: August 23, 1996; Accepted: December 31, 1997 Proofs received from author(s): April 30, 1998 